\title{
Methodological Considerations Regarding Single-Cell Gene Expression Profiling for Brain Injury*
}

\author{
Jason E. Davis, ${ }^{1}$ James H. Eberwine, ${ }^{1,2}$ David A. Hinkle, ${ }^{2,4}$ Paolo G. Marciano, ${ }^{1}$ \\ David F. Meaney, ${ }^{1,3}$ and Tracy K. McIntosh ${ }^{1,5,6}$
}

(Accepted September 5, 2003)

\begin{abstract}
Genomic microarrays are rapidly becoming ubiquitous throughout a wide variety of biological disciplines. As their use has grown during the past few years, many important discoveries have been made in the fields of central nervous system (CNS) injury and disease using this emerging technology. In addition, single-cell mRNA amplification techniques are now being used along with microarrays to overcome many of the difficulties associated with the cellular heterogeneity of the brain. This development has extended the utility of gene expression profiling and has provided researchers with exciting new insights into the neuropathology of CNS injury and disease at a molecular and cellular level. New methodological, standardization, and statistical techniques are currently being developed to improve the reproducibility of microarrays and facilitate the analysis of large amounts of data. In this review, we will discuss the application of these techniques to experimental, clinically relevant models of traumatic brain injury.
\end{abstract}

KEY WORDS: Brain injury; cDNA array; gene expression profiling; microarray standardization; RNA amplification; single cell.

\section{INTRODUCTION}

The human brain is a highly complex organ that contains many different cell types and appears to require a delicate balance of highly concerted, diverse, and dynamic gene expression in order to function properly. ${ }^{1}$ Traumatic brain injury (TBI) and other neurological insults such as stroke and epilepsy cause substantial dys-

* Special issue on Expression Profiling Within the Central Nervous System II.

${ }^{1}$ The Head Injury Center, Department of Neurosurgery, University of Pennsylvania School of Medicine, Philadelphia, Pennsylvania.

2 Department of Pharmacology, University of Pennsylvania School of Medicine, Philadelphia, Pennsylvania.

${ }^{3}$ Department of Bioengineering, University of Pennsylvania School of Medicine, Philadelphia, Pennsylvania.

${ }^{4}$ Department of Neurology, University of Pennsylvania School of Medicine, Philadelphia, Pennsylvania.

${ }^{5}$ Veterans Administration Medical Center, Philadelphia, Pennsylvania. function and cell death in the central nervous system (CNS), due in part to the perturbation of such intricately regulated networks of gene expression. ${ }^{2-9}$ The extensive damage caused by physical insults to the CNS often creates serious clinical problems that result in high mortality rates and long-term neurobehavioral consequences.

Approximately 2 million incidents of TBI per year in the United States account for over 52,000 deaths, nearly a quarter of a million hospitalizations, 500,000 people with permanent disabilities, and nearly 50 billion dollars in economic burden. ${ }^{10-13} \mathrm{TBI}$ is the leading cause of death and disability in persons under 45 years old and occurs more frequently than breast cancer, AIDS, multiple sclerosis, and spinal cord injury combined. ${ }^{13}$ The primary mechanical injury associated with TBI has been

\footnotetext{
${ }^{6}$ Address reprint requests to: Tracy K. McIntosh, Ph.D., Department of Neurosurgery, 105C Hayden Hall, 3320 Smith Walk, Philadelphia, Pennsylvania 19104-6074. Tel: (215) 573-3156; Fax: (215) 573-3808; E-mail: mcintosh@seas.upenn.edu
} 
shown to initiate a cascade of secondary or delayed cellular damage and death. ${ }^{14,15}$ The elucidation of the mechanisms underlying this secondary damage promises to enable researchers to design more effective treatments for head-injured patients to complement prevention efforts. ${ }^{16}$

Several conventional molecular biology techniques have traditionally enabled investigators to assess whether a particular gene may be involved with various physiological and disease processes by measuring the abundance of its corresponding mRNA transcript. These approaches rely on the premise that the transcription of a particular mRNA intermediate often indicates an increase in the level of the functional protein that the gene encodes. Such methods include Northern blotting (RNA-DNA hybridization), reverse transcription polymerase chain reaction (RTPCR), in situ hybridization, and RNase protection assays. These techniques are usually, however, restricted to the analysis of only a limited number of genes at a time. More recently, developed genomic technologies, such as microarrays, have provided investigators with a powerful tool to study the expression of thousands of genes simultaneously. The potential advantage to this latter approach is that alterations in regional and/or global gene expression patterns can be used to implicate specific biochemical pathways and mechanisms that underlie such complex diseases as TBI.

Microarrays can be broadly defined as solid substrates upon which numerous complimentary DNA (cDNA) or oligonucleotide probes have been imprinted. Glass and plastic slides, nitrocellulose membranes, and other similar materials have commonly been used for the array substrate. The two most commonly used types of genomic microarrays are cDNA arrays, which generally contain a single target for each probe RNA, and oligonucleotide microarrays which contain multiple nucleic acid fragments of a particular length that correspond to various partial gene sequences. On the basis of these two architectures, a tremendous number of platforms are currently available. ${ }^{17,18}$ However, all microarrays generally rely on common methodologies. RNA is extracted from a biological sample, either a fluorescent or radioactive tag is incorporated, and experimental samples are hybridized to the substrate-bound nucleic acid targets. ${ }^{19}$ Each array is then thoroughly washed and scanned, and specialized software is used to analyze the resulting image by quantifying the relative intensities of the experimental and control samples for each gene represented on the array.

Despite the power of arrays to detect parallel changes in gene expression, microarray assays are still a relatively new technique and are considered most effective when employed as a primary screen. More traditional techniques, such as real-time RT-PCR, Northern blotting, and in situ hybridization, are commonly used to confirm the expression patterns of genes identified to be differentially expressed on the microarrays. ${ }^{20}$ In situ hybridization also offers the added benefit of providing information about the localization of individual mRNAs. ${ }^{21,22}$ Together, the combination of genomic microarrays and traditional molecular biology techniques provides a reliable and powerful set of tools to detect patterns of differential gene expression in the brain and other tissues. Techniques such as immunohistochemistry, Western blotting, and EnzymeLinked Immunosorbent Assay (ELISA) can then be used to analyze more directly individual protein levels and localization. Techniques are currently being developed for screening large numbers of proteins simultaneously, ${ }^{23}$ but they must also contend with additional post-translational modifications that are not encoded in the genome. Transgenic animals and other methods of genomic manipulation have also been used extensively with animal models of TBI to demonstrate mechanistic information about the function of individual genes and their encoded protein gene products. $^{24}$

\section{GENE EXPRESSION PROFILING USING BRAIN HOMOGENATES}

Many early microarray studies relied on the total RNA isolated from tissue homogenates for gene expression analysis. Two major advantages to using homogenized brain tissue for gene expression profiling include the relatively large amount of starting material and the potential to obtain insight regarding how the intact system functions as a whole at the genomic level. Several examples of studies that have used microarray analysis of brain homogenates during the past few years to examine gross regional gene expression profiles in rodent models of such complex brain disorders as TBI, stroke, and epilepsy are summarized in Table I, along with the species, conditions, and types of arrays that were used for each comparison. ${ }^{25-33}$ All five of the TBI studies listed in Table I employed a controlled cortical impact (CCI) model of injury, but different strains and species were used in the different studies. The microarrays most frequently used for all of the rat studies were the Affymetrix U34 Rat Neurobiology array and U34 Rat Genome Set, whereas different arrays were used for each of the mouse studies. Although Kobori et al. ${ }^{28}$ analyzed gene expression at five intervals between $2 \mathrm{~h}$ and 14 days, all of the other studies evaluated relatively acute time points after injury. 
Table I. Recent Microarray Studies That Have Used Tissue Homogenate to Compare Regional Gene Expression Profiles in Rodent Models of Brain Injury and Their Applied Conditions and Methodologies

\begin{tabular}{|c|c|c|c|c|}
\hline Source & Injury & Region analyzed & Array/amplification & Comparisons \\
\hline Rall et al. ${ }^{25}$ & $\begin{array}{l}\mathrm{CCI}(\text { male Long-Evans } \\
\text { rats, } 250 \mathrm{~g}-275 \mathrm{~g})^{\mathrm{a}}\end{array}$ & $\begin{array}{l}\text { Cortex anterior to impact } \\
\text { site, hippocampus } \\
\text { ( } 24 \mathrm{~h} \text { postinjury) }\end{array}$ & $\begin{array}{l}\text { Affymetrix Rat Genome } \\
\text { U34A GeneChip, aRNA } \\
\text { (T7) amplification }\end{array}$ & $\begin{array}{l}\text { Ipsilateral injured vs. } \\
\text { sham frontal cortex } \\
\text { and sham hippocampus; } \\
\text { sham frontal cortex } \\
\text { vs. sham hippocampus } \\
\text { ( } \mathrm{n}=10 \text { pooled) }\end{array}$ \\
\hline Rao et al. ${ }^{26}$ & $\begin{array}{l}\text { CCI (male Sprague-Dawley } \\
\text { rats, } 250 \mathrm{~g}-280 \mathrm{~g})^{\mathrm{a}}\end{array}$ & $\begin{array}{l}\text { Cortex }(3 \mathrm{~h}, 9 \mathrm{~h} \text {, and } \\
24 \mathrm{~h} \text { postinjury) }\end{array}$ & $\begin{array}{l}\text { Affymetrix Rat Genome } \\
\text { U34 GeneChip }\end{array}$ & $\begin{array}{l}\text { Ipsilateral injured cortex } \\
\text { vs. sham }(\mathrm{n}=3 \text { were } \\
\text { pooled, } 3 \mathrm{~h} \text { and } 24 \mathrm{~h} \\
\text { shams combined) }\end{array}$ \\
\hline Long et al. ${ }^{27}$ & $\begin{array}{l}\mathrm{CCI}(\text { male c57/BL6 } \\
\text { mice, } 20 \mathrm{~g}-30 \mathrm{~g})^{\mathrm{a}}\end{array}$ & $\begin{array}{l}\text { Hippocampus ( } 4 \mathrm{~h} \text { and } \\
24 \mathrm{~h} \text { postinjury) }\end{array}$ & $\begin{array}{l}\text { Custom cDNA microarrays } \\
\text { fabricated by Baylor } \\
\text { College of Medicine }\end{array}$ & $\begin{array}{l}\text { Ipsilateral injured } \\
\text { hippocampus vs. sham } \\
\text { ( } \mathrm{n}=6 \text { to } 9 \text { per each } \\
\text { chin }\end{array}$ \\
\hline Kobori et al..$^{28}$ & $\begin{array}{l}\mathrm{CCI}(\text { male c57/BL6 } \\
\text { mice, } 20 \mathrm{~g}-27 \mathrm{~g})^{\mathrm{a}}\end{array}$ & $\begin{array}{l}\text { Cortex }(2 \mathrm{~h}, 6 \mathrm{~h}, 24 \mathrm{~h}, 3 \text { days, } \\
\text { and } 14 \text { days postinjury) }\end{array}$ & $\begin{array}{l}\text { Incyte GEM } 2 \text { cDNA } \\
\text { microarray chips }\end{array}$ & $\begin{array}{l}\text { Ipsilateral injured frontal } \\
6 \mathrm{~mm} \text { of cortex vs. } \\
\text { naive ( } \mathrm{n}=10 \text { pooled })\end{array}$ \\
\hline Matzilevich et al. ${ }^{29}$ & $\begin{array}{l}\text { CCI (male Long-Evans } \\
\text { rats, } 250 \mathrm{~g}-275 \mathrm{~g})^{\mathrm{a}}\end{array}$ & $\begin{array}{l}\text { Hippocampus ( } 3 \mathrm{~h} \text { and } \\
24 \mathrm{~h} \text { postinjury) }\end{array}$ & $\begin{array}{l}\text { Affymetrix Rat Genome } \\
\text { U34A GeneChip, aRNA } \\
\text { (T7) amplification }\end{array}$ & $\begin{array}{l}\text { Ipsilateral injured } \\
\text { hippocampus vs. sham } \\
\text { ( } \mathrm{n}=10 \text { were pooled })\end{array}$ \\
\hline Rao et al. ${ }^{30}$ & $\begin{array}{l}\text { MCAO (male spontaneously } \\
\text { hypertensive rats, } 280 \mathrm{~g}-320 \mathrm{~g} \text { ) }\end{array}$ & $\begin{array}{l}\text { Frontoparietal cortex } \\
\quad(6 \mathrm{~h} \text { and } 24 \mathrm{~h} \text { postinfarction })\end{array}$ & $\begin{array}{l}\text { Affymetrix Rat Neurobiology } \\
\text { U34 GeneChip }\end{array}$ & $\begin{array}{l}\text { Ipsilateral injured cortex } \\
\text { vs. contralat. cortex }(\mathrm{n}=3 \\
\text { per each of } 3 \text { chips per } \\
\text { group were pooled) }\end{array}$ \\
\hline Schmidt-Kastner et al. ${ }^{31}$ & $\begin{array}{l}\text { MCAO (male Sprague-Dawly } \\
\text { rats, } 263 \mathrm{~g}-370 \mathrm{~g} \text { ) }\end{array}$ & $\begin{array}{l}\text { Peri-ischemic cortex } \\
\quad(3 \mathrm{~h} \text { postinfarction })\end{array}$ & $\begin{array}{l}\text { Incyte Mouse UniGene } 1 \\
\text { microarray }\end{array}$ & $\begin{array}{l}\text { Ipsilateral injured cortex vs. } \\
\text { sham }(\mathrm{n}=2 \text { per each of } 3 \\
\text { chips per group were pooled) }\end{array}$ \\
\hline Elliott et al. ${ }^{32}$ & $\begin{array}{l}\text { Drug-induced and terminated } \\
\text { status epilepticus (male } \\
\text { Sprague-Dawley rats, } 180 \mathrm{~g}-200 \mathrm{~g} \text { ) }\end{array}$ & $\begin{array}{l}\text { Dentate gyrus: } 14 \text { days after } \\
\text { status epilepticus (SE) and } \\
3 \text { days postnatal }\end{array}$ & $\begin{array}{l}\text { Affymetrix Rat Genome } \\
\text { U34A GeneChip }\end{array}$ & $\begin{array}{l}\text { Bilateral dentate gyrus after SE } \\
\text { vs. } \mathrm{P} 3(\mathrm{n}=2 \text { to } 3 \text { from adult } \\
\text { or } \mathrm{n}=10 \text { to } 12 \text { from } \mathrm{P} 3 \\
\text { animals pooled) }\end{array}$ \\
\hline Lukasiuk et al. ${ }^{33}$ & $\begin{array}{l}\text { Amygdala stimulation with } \\
\text { electrode (male Sprague-Dawley } \\
\text { rats, } 290 \mathrm{~g}-360 \mathrm{~g})\end{array}$ & $\begin{array}{l}\text { Temporal lobe and hippocampus } \\
(1 \text { day, } 4 \text { days, } 1 \text { week, } 2 \text { weeks } \\
\text { with seizures and } 2 \text { weeks without } \\
\text { seizures after SE })\end{array}$ & $\begin{array}{l}\text { Research Genetics GF300 } \\
\text { filter cDNA microarrays }\end{array}$ & $\begin{array}{l}\text { Bilateral hippocampus and } \\
\text { temporal lobes after SE vs. } \\
\text { controls ( } \mathrm{n}=2 \text { to } 3 \text { were } \\
\text { pooled per chip per group) }\end{array}$ \\
\hline
\end{tabular}

CCI-Controlled Cortical Impact brain injury.

${ }^{\mathrm{b}}$ MCAO-Middle Cerebral Artery Occlusion. 


\section{SINGLE-CELL GENE EXPRESSION PROFILING}

Although regional gene expression analysis of brain homogenates has continued to yield valuable information, this approach does not account for the complex cellular heterogeneity of the brain. ${ }^{21,34-36}$ Instead, it combines all of the different cell types present in a sample tissue (neurons, glia, blood cells and vessels, and so forth) at potentially disparate stages of injury and disease processes. ${ }^{25-33}$ As a result, the gene expression profiles of selectively vulnerable subpopulations of cells may be largely obscured, and the detection of potentially important, less abundantly expressed genes (such as transcription factors) may be overlooked. Identification of the source of an observed pattern of differential gene expression can also be more difficult when tissue homogenates are used for gene expression profiling.

One method that investigators have used to overcome some of the challenges associated with the complex cellular heterogeneity of the brain is single-cell gene expression profiling. ${ }^{36-38}$ By focusing on only one cell or cell type at a time, single-cell analysis can be used to reduce the level of background signal caused by inherent differences in the gene expression of many different cells within a particular experimental sample. Several studies have exploited this capacity to characterize changes in gene expression among specific subpopulations of cells and cell types under both normal and pathological conditions (Table II).,21-22,39-43 An investigator may also choose to pool multiple cells of a common phenotype or those that meet specific criteria in order to account for normal biological variability between individual cells and/or animals. ${ }^{19,41-42}$ In order to ensure that enough genetic material is available for subsequent gene expression analysis, amplification of the RNA obtained from a single cell is required. ${ }^{34,36,38}$ Single-cell microarray analysis has, therefore, been made possible, in large part, by advances in RNA amplification.

There are currently two accepted nucleic acid amplification procedures available, the polymerase chain reaction (PCR) and the antisense RNA (aRNA) amplification procedures. ${ }^{38,44} \mathrm{PCR}$ is a straightforward technique for amplifying large amounts of complementary DNA (cDNA) from relatively small initial quantities of poly $(\mathrm{A})^{+}$sample RNA. After an initial reverse transcription reaction to produce the corresponding cDNA of an RNA sample, Taq DNA polymerase is used along with a series of oligonucleotide primers to amplify exponentially the resulting cDNA product through repeated cycles. The cDNA synthesis rates, however, can vary for individual mRNAs of different lengths, and the effi- ciency with which Taq polymerase amplifies different cDNAs can vary depending on the $\mathrm{G} / \mathrm{C}$ composition of the template sequence. Because each amplification product is then replicated logarithmically, any aberration in the concentration of an individual mRNA that occurs in any step of the PCR can cause the final amplification product to no longer accurately represent the original relative abundance of endogenous cellular mRNAs. Additionally, high-abundance mRNAs can outcompete low- and medium-abundance mRNAs for the primer pairs. As a result, the complexity of the final amplified cDNA population after 30 to 40 successive PCR cycles can be lower than that of the initial pool. ${ }^{36}$

In contrast to PCR, amplification by the aRNA method increases the amount of RNA present in a sample linearly by directly amplifying the original cDNA template. ${ }^{38}$ Therefore, the amplification products generated by aRNA amplification appear to better represent the relative abundances of mRNAs present in the initial mRNA pool. This linearity can be attributed to the highly efficient T7 polymerase used for amplification and has been examined by several groups using microarrays, Northern blotting, and RT-PCR. ${ }^{21,36,45}$ The basic aRNA amplification protocol involves first incorporating a specialized oligo-dT primer that contains the sequence of a T7 RNA polymerase promoter into the complementary DNA of the sample mRNAs. Many copies are then generated from each original cDNA in a subsequent RNA polymerase reaction (Fig. 1). Yields typically reach between 1000- to 5000-fold following only two rounds of in vitro transcription. This technique can be applied to live cells, tissue homogenates, or fixed tissues. ${ }^{39,46}$

Before RNA can be obtained for amplification, individual cells must first be harvested from tissue. The identification of cells for single-cell gene expression analysis is generally accomplished by implementing a series of selection criteria on the basis of cellular morphology, immunohistochemical markers, histochemical labeling, and/or distinct gene expression patterns determined by a technique such as in situ hybridization.,39

Identified cells are then typically harvested by one of two ways. The first, and still simplest method of cell selection, uses a micromanipulator and microcapillary electrode attached to a dissecting microscope to aspirate individual cells from a culture dish or slide-mounted tissue section. ${ }^{36,38-39}$ The sample RNA is then transferred to a microcentrifuge tube for subsequent amplification and analysis.

Marciano et al. ${ }^{39}$ recently implemented such methodologies along with a combination of terminal deoxyribonucleotidyl transferase-mediated biotinylated dUTP nicked end labeling (TUNEL) and caspase-3 immunohistochemistry in order to select damaged and dying cells 
Table II. Examples of Study Conditions and Methodologies Used to Evaluate the Gene Expression Profiles of Single Cells in the Central Nervous System

Tietjen et al..$^{22}$

Hemby et al. ${ }^{41}$ Age-matched adult male
schizophrenic human tissue (postmortem)

Crino et al. ${ }^{42}$

2-11 year old human tuberous sclerosis (TSC) tissue obtained during epilepsy surgery

Miyashiro et al. ${ }^{43} \quad$ Naïve E20-21 (embryonic day 20-21) rat hippocampal cell cultures
Pyramidal CA3 cells of the
hippocampus and granula cells of the dentate gyrus

Cortical neurons selected from the peri-contusional cortex

CA1 pyramidal neurons and interneurons of the hippocampus

CA1 pyramidal neurons and interneurons of the hippocampus

Mature olfactory sensory neurons* (OSN); olfactory progenitor cells $s^{\dagger}$ (OPC)

Enthorhinal cortical pyramidal neurons

Cortical tubers from frontal and temporal neocortex

Morphologically identified hippocampal neurons, isolate from low-density cultures
Comparisons

TUNEL/Caspase3: +/+ vs. +/vs. $-/-$ and pyramidal vs. granular cells ( 2 cells pooled per $\mathrm{n}=3$ per each criteria) TUNEL-positive injured vs.

TUNEL-negative injured vs.

TUNEL-negative sham

pyramidal neurons

Custom small-scale cDNA microarrays printed and hybridized in-house, aRNA (T7) amplification

Custom cDNA microarrays printed and hybridized in-house, aRNA
amplification

Affymetrix HuGeneFL and Mu11K high-density oligonucleotide microarrays, PCR (Taq) cDNA amplification

National Institute on Aging (NIA) cDNA microarrays; aRNA (T7) amplification

Biocytin-filled CA1 excitatory pyramidal neurons vs. adjacent CA1 inhibitory stellate interneurons

Cresyl violet stained CA1

hippocampal neurons vs. adjacent CA1 interneurons

Mature OSNs vs. embryonic OPCs, identified by Southern hybridization of cDNA amplification product RMDO-20-stained pyramida neurons from schizophrenia brains vs. pyramidal neuron from normal control brains

cDNA reverse Northern blot, aRNA (T7) amplification

Nestin-labelled TSC neurons vs. nestin-labelled TSC giant cells vs. whole TSC tuber sections vs. normal controls (postmortem)

DNA reverse Northern blot, aRNA (T7) amplification

Neuronal cell bodies and neuronal

processes/neurites

Note: *Mature olfactory sensory neurons obtained from adult olfactory epithelium. ${ }^{\dagger}$ Olfactory progenitor cells obtained from embryonic day 15 (E15) olfactory epithelium.

${ }^{a}$ CCI-Controlled Cortical Impact brain injury.

${ }^{b}$ LFP-Lateral Fluid Percussion brain injury. 


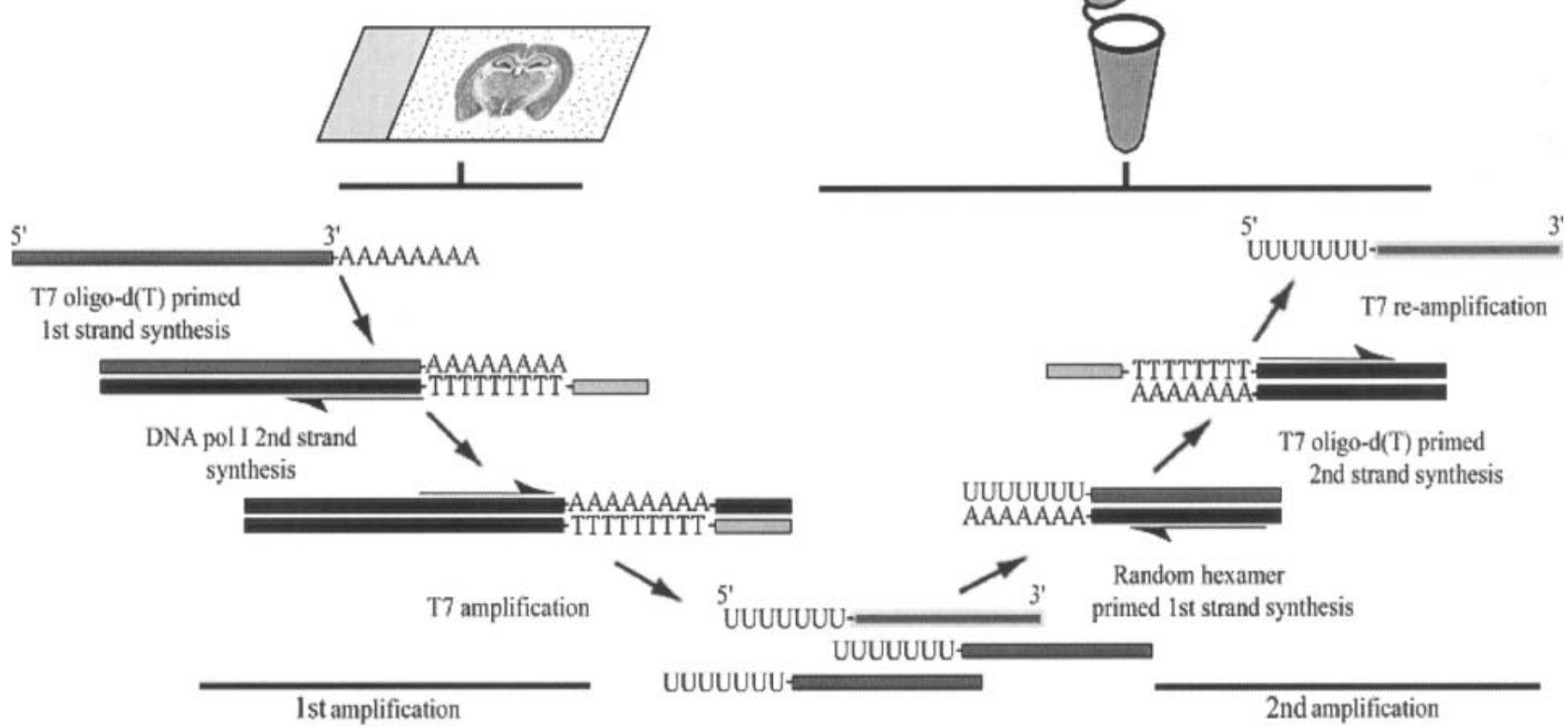

Fig. 1. Schematic illustration of aRNA (T7) amplification procedure (modified from $\mathrm{Kelz}^{48}$ ).

from the CA3 and dentate gyrus regions of the hippocampus following a CCI model of traumatic brain injury. The cells, identified as either TUNEL -/caspase-3-,
TUNEL +/caspase-3-, or TUNEL +/caspase-3+, were chosen to represent three different stages of cell damage and apoptotic cell death (Fig. 2). Subsequent aRNA ampli-

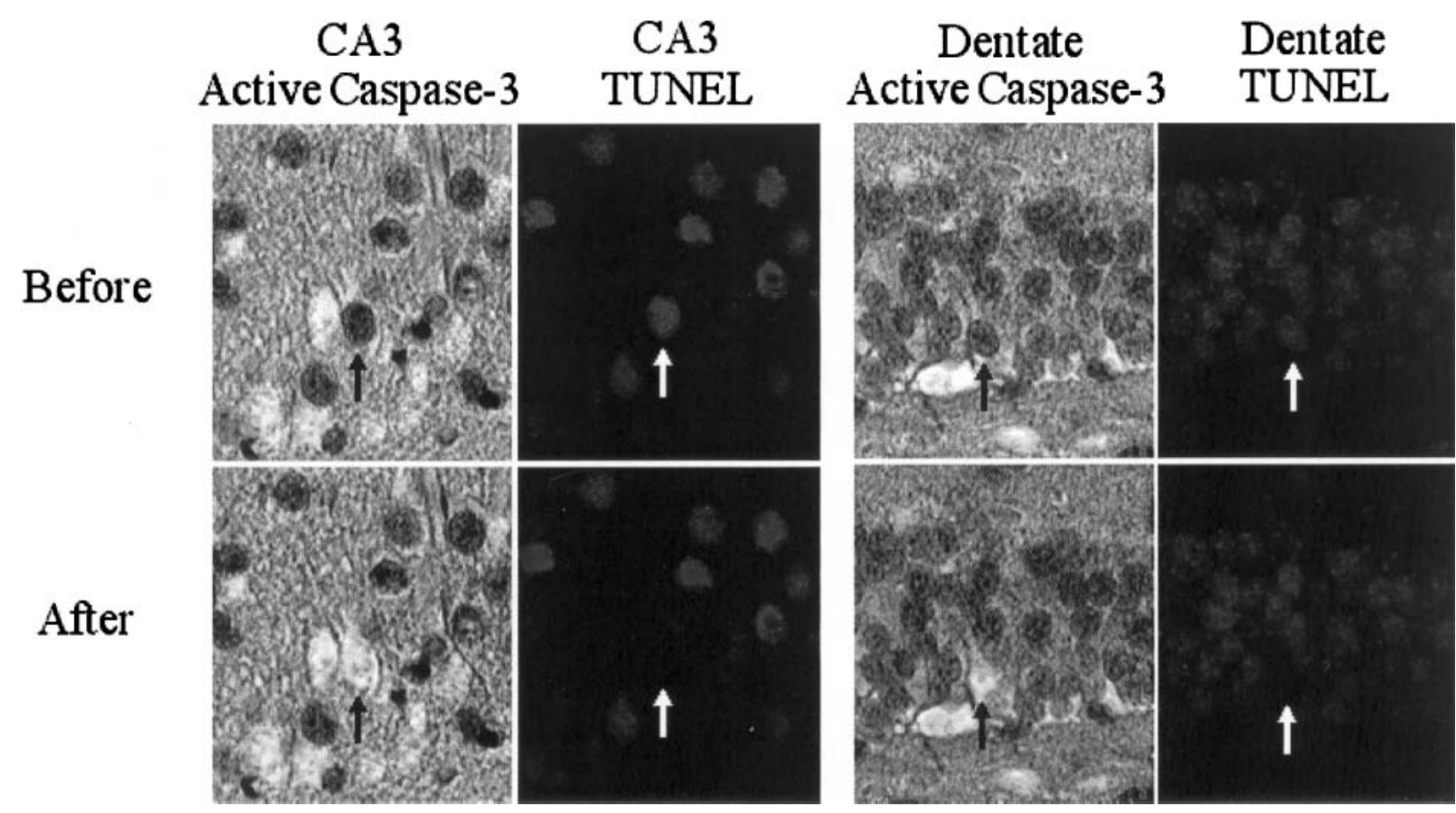

Fig. 2. Aspiration of caspase- 3 immunohistochemically labeled and TUNEL-positive cells in the CA3 and dentate gyrus of a CCI-injured mouse hippocampus for subsequent gene expression analysis (Marciano, P.G., unpublished data). 
fication and cDNA microarray analysis was then used to identify novel genes that were not previously suspected to be involved with the progression of an injured cell through various stages of damage and apoptosis following TBI.

More recently, laser capture microdissection (LCM) has also become a popular method for isolating nucleic acids from tissue samples. ${ }^{47}$ Laser microdissection essentially involves using either a high-energy cutting laser to ablate surrounding tissue or a lower energy laser to melt and attach a thin film to the desired section, which can then be used to "capture" the single-cell sample. ${ }^{48}$ A shortcoming to the latter LCM method is that it requires the use of unfixed tissue, introducing a greater potential for contamination by active endogenous RNases. Kamme et al. ${ }^{21}$ recently demonstrated LCM along with aRNA amplification and cDNA microarray analysis in a study designed to evaluate cellular heterogeneity in the CA1 region of the rat hippocampus. Both microdissection methods are effective and share similar stipulations regarding the contamination of a sample from neighboring cells and tissue. With care and experience, however, such imperfections can usually be minimized.

\section{ADDITIONAL CHALLENGES FACING USERS AND DEVELOPERS OF GENOMIC MICROARRAYS}

Despite the power of arrays to detect changes in the expression of thousands of gene simultaneously, microarray assays are complex, multistep procedures, and there are several points at which experimental and systematic variability can be introduced. Even the vast number of methods that are currently available to organize and statistically analyze the resulting plethora of data obtained can complicate microarray analysis. ${ }^{49}$ However, experimental variability can usually be minimized through careful experimental design and repetition. Systematic variability, which can include array fabrication irregularities and dye-associated biases, ${ }^{50,51}$ can often be reduced by reversing the dyes used for experimental and control samples on repeated arrays and by incorporating appropriate control groups and internal positive and negative controls. Benes and Muckenthaler, ${ }^{51}$ recently suggested that the inclusion of exogenous negative and spike-in controls should be mandatory to facilitate the comparison of data between laboratories. Each of these quality-control measures adds to the value of microarray data by enhancing the ability of independent labs to reproduce an array. Yet, the most compelling validation of gene expression profiling data is often achieved by following up on the obtained data using a variety of traditional methods to characterize further the differentially expressed genes and the function of their corresponding gene products. ${ }^{17,20}$

During the past few years, in order to facilitate the confirmation of published results by independent investigators, many publications have implemented detailed guidelines for reporting microarray data. ${ }^{53,54}$ These criteria generally require authors to specify details about experimental design, including samples used, extract preparation and labeling, hybridization procedure and parameters, measurement data, and specifications and array design. However, despite such conditions for reporting microarray data, some concerns have been expressed regarding the difficulty of comparing gene expression data sets across different microarray platforms and between different laboratories. ${ }^{49-51}$ In order to account for biological diversity and demonstrate experimental consistency, adequate biological and technical replication should be incorporated into the design of a study by using multiple tissue samples and repeated arrays. Duplicate measurements of a single sample on a single chip should not be misinterpreted as an indication of the reproducibility of an individual array. ${ }^{19}$

In addition to genomic microarrays, several other methods such as serial analysis of gene expression (SAGE) are currently being developed as alternative technologies for gene expression profiling. ${ }^{55}$ In SAGE, gene activity is identified by sequencing long DNA molecules representing a series of 9-10 base pair tags that have been cut from reverse-transcribed cDNA using a class II restriction endonuclease, ligated together, and PCR amplified. Once the resulting gene products are sequenced, the frequency of each expressed sequenced tag (EST) is considered to reflect its absolute abundance in the experimental mRNA pool. In one recent study, SAGE was used to identify metallothionein-II as a neuroprotective gene in mouse focal cerebral ischemia, ${ }^{56}$ whereas another study recently suggested that SAGE may offer greater sensitivity than an Affymetrix oligonucleotide microarray. ${ }^{57}$ However, concerns about the specificity and reproducibility of SAGE remain deterrents, and its cost and requirement for a large amount of input mRNA currently limit its use. During the past few years, several modifications have been made to the protocol to create a protocol referred to as micro-SAGE, which allows the generation of SAGE libraries from small quantities of starting material. ${ }^{58}$ Single-cell SAGE, however, is not yet available. Users of both SAGE and micro-SAGE must currently also contend with all of the same problems regarding PCR amplification as those discussed above for microarrays. 


\section{CONCLUSIONS}

Microarrays and other gene expression profiling techniques have already facilitated many new and exciting insights into the biology of brain injury and other neurological diseases through the correlation of specific gene expression patterns with changes fundamental to complex disease states. As genomic technologies continue to improve and become more standardized and affordable, such techniques will likely continue to be one of the most extensively used techniques in coming years. Furthermore, the standardization of mRNA amplification and microarray technologies promises to facilitate crossstudy comparisons of gene expression profiles obtained by different laboratories under similar conditions.

Future applications of microarrays for brain disorders will likely include the further characterization of the pathological cascades that follow CNS insults such as TBI, stroke, and epilepsy. Also important will be the inclusion of experiments to address fundamental questions about neural stem cell biology in the context of transplantation and other similar regenerative strategies. Such studies will likely require greater emphasis on the postexpression processing, regulation, and functions of differentially expressed mRNAs and their encoded proteins than many previous studies have provided. In order for the full potential of techniques for gene expression profiling to be recognized, investigators will need to perform and publish rigorous studies that follow up on data obtained from gene expression profiling experiments. The application of microarrays and other similar gene expression profiling technologies offers new hope that an improved understanding of gene expression may ultimately improve the lives of brain-injured patients by facilitating the development of new and effective treatment strategies for such devastating diseases and disorders as TBI.

\section{ACKNOWLEDGMENTS}

This work was supported, in part, by NIH Grants NS08803 (T. K. M. and J. H. E.), NS40978 (T. K. M.), GM34690 (T. K. M), and NICHD 41699 (D. F. M.), a Veterans Administration Merit Review Grant (T. K. M.), and a Veterans Administration D.O.D. Consortium Grant (T. K. M.). Thank you to Jeanne Marks for manuscript preparation.

\section{REFERENCES}

1. Sutcliffe, J. G. 1988. mRNA in the mammalian central nervous system. Ann. Rev. Neurosci. 11:157-198.

2. O’Dell, D. M., Raghupathi, R., Crino, P. B., Eberwine, J. H., McIntosh, T. K. 2000. Traumatic brain injury alters the molecular fingerprint of TUNEL-positive cortical neurons in vivo: a singlecell analysis. J. Neurosci. 20(13):4821-4828.

3. Clark, R. S. B., Chen, J., Watkins, S. C., et al. 1997. Apoptosissuppressor gene bcl-2 expression after traumatic brain injury in rats. J. Neurosci. 17:9172-82.

4. Yang, K., Mu, X. S., Xue, J. J., et al. 1994. Increased expression of c-fos mRNA and AP-1 transcription factors after cortical impact injury in rats. Brain Res. 664:141-7.

5. DeKosky, S. T., Goss, J. R., Miller, P. D., Styren, S. D., Kochanek, P. M., and Marion D. 1994. Upregulation of nerve growth factor following cortical trauma. Exp Neurol. 130:173-7.

6. Hicks, R. R., Numan, S., Dhillon, H. S., Prasad, M. R., and Seroogy, K. B. 1997. Alterations in BDNF and NT-3 mRNAs in rat hippocampus after experimental brain trauma. Mol. Brain. Res. 48: 401-6.

7. Kogure, K. and Kato, H. 1993. Altered gene expression in cerebral ischemia. Stroke 24(12):2121-2127.

8. Nogawa, S., Zhang, F., Ross, M.E., and Iadecola, C. 1997. Cyclooxygenase-2 gene expression in neurons contributes to ischemic brain damage. J. Neurosci. 17(8):2746-2755.

9. French, P. J., O'Connor, V., Voss, K., Stean, T., Hunt, S. P., and Bliss, T. V. 2001. Seizure-induced gene expression in area CA1 of the mouse hippocampus. Eur. J. Neurosci. 14(12):2037-2041.

10. Centers for Disease Control. 2001. "Traumatic Brain Injury in the United States: A Report to Congress." http://www.cdc.gov/ncipc/ pub-res/tbi_congress/index.htm.

11. McGarry, L. J., Thompson, D., Millham, F. H., Cowell, L., Snyder, P. J., Lenderking, W. R., and Weinstein, M. C. 2002. Outcomes and costs of acute treatment of traumatic brain injury. J. Trauma 53(6): 1152-1159.

12. Lewin, I. C. F. 1992. The cost of disorders of the brain, Washington, DC: The National Foundation for the Brain, 1992.

13. Brain Injury Association of America. 2004. Data compiled and arranged based on data from the Centers for Disease Control and Prevention, American Cancer Society, and National Multiple Sclerosis Society. http://www.biausa.org/Pages/facts_and_stats.html.

14. Raghupathi, R., McIntosh, T. K., and Smith, D. H. 1995. Cellular responses to experimental brain injury. Brain Pathol. 5(4): 437-442.

15. Conti, A. C., Raghupathi, R., Trojanowski, J. Q., and McIntosh, T. K. 1998. Experimental brain injury induces regionally distinct apoptosis during the acute and delayed post-traumatic period. J. Neurosci. 18(15):5663-5672.

16. Jain, K. K. 2000. Applications of biochip and microarray systems in pharmacogenomics. Pharmacogenomics 1(3):289-307.

17. Shilling, P. D. and Kelsoe, J. R. 2002. Functional genomics approaches to understanding brain disorders. Pharmacogenomics 3(1):31-45.

18. Constans, A. 2003. The state of the microarray. The Scientist 17(3):34-41.

19. Churchill, G. A. 2002. Fundamentals of experimental design for cDNA microarrays. Nat. Genet. 32:490-495.

20. Chuaqui, R. F., Bonner, R. F., Best, C. J. M., Gillespie, J. W., Flaig, M. J., Hewitt, S. M., Phillips, J. L., Krizman, D. B., Tangrea, M. A., Ahram, M., Linehan, W. M., Knezevic, V., and Emmert-Buck, M. R. 2002. Post-analysis follow-up and validation of microarray experiments. Nat. Genet. 32:509-514.

21. Kamme, F., Salunga, R., Yu, J., Tran, D-T., Zhu, J., Luo, L., Bittner, A., Guo, H-Q., Miller, N., Wan, J., and Erlander, M. 2003. Single-cell microarray analysis in hippocampus CA1: demonstration and validation of cellular heterogeneity. J. Neurosci. 23(9): 3607-3615.

22. Tietjen, I., Rihel, J. M., Cao, Y., Koentges, G., Zakhary, L, and Dulac, C. 2003. Single-cell transcriptional analysis of neuronal progenitors. Neuron 38:161-175.

23. Zhang, H. T., Kacharmina, J. E., Miyashiro, K., Greene, M. I., and Eberwine, J. 2001. Protein quantification from complex protein mixtures using a proteomics methodology with single-cell resolution. Proc. Natl. Acad. Sci. USA 98(10):5497-5502. 
24. Longhi, L., Saatman, K. E., Raghupathi, R., Laurer, H. L., Lenzlinger, P. M., Riess, P., Neugebauer, E., Trojanowski, J. Q. Lee, V. M., Grady, M. S., Graham, D. I., and McIntosh, T. K. 2001. A review and rationale for the use of genetically engineered animals in the study of traumatic brain injury. J. Cereb. Blood. Flow. Metab. 21(11):1241-1258.

25. Rall, J. M., Matzilevich, D. A., and Dash, P. K. 2003. Comparative analysis of mRNA levels in the frontal cortex and the hippocampus in the basal state and in response to experimental brain injury. Neuropathol. Appl. Neurobiol. 29:118-131.

26. Rao, V. L. R., Dhodda, V. K., Song, G., Bowen, K. K., and Dempsey, R. J. 2003. Traumatic brain injury-induced acute gene expression changes in rat cerebral cortex identified by GeneChip analysis. J. Neurosci. Res. 71:208-219.

27. Long, Y., Zou, L., Liu, H., Lu, H., Yuan, X., Robertson, C. S., and Yang, K. 2003. Altered expression of randomly selected genes in mouse hippocampus after traumatic brain injury. J. Neurosci. Res. 71:710-720.

28. Kobori, N., Clifton, G. L., and Dash, P. K. 2002. Altered expression of novel genes in the cerebral cortex following experimental brain injury. Mol. Brain Res. 104:148-158

29. Matzilevich, D. A., Rall, J. M., Moore, A. N., Grill, R. J., and Dash, P. K. 2002. High-density microarray analysis of hippocampal gene expression following experimental brain injury. J. Neurosci. Res. 67:646-663.

30. Rao, V. L. R., Bowen, K. K., Dhodda, V. K., Song, G., Franklin, J. L., Gavva, N. R., and Dempsey, R. J. 2002. Gene expression analysis of spontaneously hypertensive rat cerebral cortex following transient focal cerebral ischemia. J. Neurochem. 83: 1072-1086.

31. Schmidt-Kastner, R., Zhang, B., Belayev, L., Khoutorova, L., Amin, R., Busto, R., and Ginsberg, M. D. 2002. DNA microarray analysis of cortical gene expression during early recirculation after focal brain ischemia in rat. Mol. Brain Res. 108:81-93.

32. Elliott, R. C., Miles, M. F., and Lowenstein, D. H. 2003. Overlapping microarray profiles of dentate gyrus gene expression during development- and epilepsy-associated neurogenesis and axon outgrowth. J. Neurosci. 23(6):2218-2227.

33. Lukasiuk, K., Kontula, L., and Pitkanen, A. (2003). cDNA profiling of epileptogenesis in the rat brain. Eur. J. Neurosci. 17(2): 271-279.

34. Levsky, J. M. and Singer, R. H. 2003. Gene expression and the myth of the average cell. Trends Cell Biol. 13(1):4-6.

35. Geschwind, D. H. 2000. Mice, microarrays, and the genetic diversity of the brain. PNAS 97(20):10676-10678.

36. Eberwine, J. H., Yeh, H., Miyashiro, K., Cao, Y., Nair, S., Finnell, R., Zettel, M., and Coleman, P. 1992. Analysis of gene expression in single live neurons. PNAS 89(7):3010-3014.

37. Eberwine, J., Kacharmina, J. E., Andrews, C., Miyashiro, K., McIntosh, T. K., Becker, K., Barrett, T., Hinkle, D., Dent, G., Marciano, P. 2001. mRNA expression analysis of tissue sections and single cells. J. Neurosci. 1(21):8310-8314.

38. Van Gelder, R. N., von Zastrow, M. E., Yool, A., Dement, W. C., Barchas, J. D., and Eberwine, J. H. 1990. Amplified RNA synthesized from limited quantities of heterogeneous cDNA. PNAS 87(5):1663-1667.

39. Marciano, P. G., Brettschneider, J., Manduchi, E., Eastman, S., Raghupathi, R., Saatman, K., Speed, T. P., Stoeckert, Jr., C. J. Eberwine, J. H., and McIntosh, T. K., Neuron-specific mRNA complex responses to trauma-induced hippocampal apoptosis. J. Neuroscience (in press).

40. Telfeian, A. E., Tseng, H. C., Baybis, M., Crino, P. B., and Dichter, M. A. 2003. Differential expression of GABA and glutamatereceptor subunits and enzymes involved in GABA metabolism between electrophysiologically identified hippocampal CA1 pyramidal cells and interneurons. Epilepsia 44(2):143-149.

41. Hemby, S. E., Ginsberg, S. D., Brunk, B., Arnold, S. E., Trojanowski, J. Q., and Eberwine, J. H. 2002. Gene expression profile for schizophrenia: discrete neuron transcription patterns in the entorhinal cortex. Arch. Gen. Psychiatry 59(7):631-640.

42. Crino, P. B., Trojanowski, J. Q., Dichter, M. A., and Eberwine, J. 1997. embryonic neuronal markers in tuberous sclerosis: singlecell molecular pathology. Proc. Natl. Acad. Sci. USA 93(24): 14152-14157.

43. Miyashiro, K., Dichter, M., and Eberwine, J. 1994. On the nature and differential distribution of mRNAs in hippocampal neurites: implications for neuronal functioning. Proc. Natl. Acad. Sci. USA 91(23):10800-10804.

44. Saiki, R. K., Bugawan, T. L., Horn, G. T., Mullis K. B., and Erlich, H. A. 1986. Analysis of enzymatically amplified beta-globin and HLA-DQ alpha DNA with allele-specific oligonucleotide probes. Nature 324(6093): 163-166.

45. Luo, L., Salunga, R. C., Guo, H., Bittner, A., Joy, K. C., Galindo, J. E., Xiao, H., Rogers, K. E., Wan, J. S., Jackson, M. R., and Erlander, M. G. 1999. Gene expression profiles of laser-captured adjacent neuronal subtypes. Nat. Med. 5(1):117-122.

46. Eberwine, J. H. and Crino, P. 1997. Analysis of mRNA populations from single live and fixed cells of the central nervous system. Curr. Protoc. Neurosci. 5:1-15.

47. Todd, R. and Margolin, D. H. 2002. Challenges of single-cell diagnostics: analysis of gene expression. Trends Mol. Med. 8(6): 254-257.

48. Emmert-Buck, M. R., Bonner, R. F., Smith, P. D., Chuaqui, R. F., Zhuang, Z., Goldstein, S. R., Weiss, R. A., and Liotta, L. A. 1996. Laser capture microdissection. Science 274(5289):998-1001.

49. Butte, A. 2002. The use and analysis of microarray data. Nat. Rev. Drug Discov. 1(12):951-960.

50. Mirnics, K. 2001. Microarrays in brain research: the good, the bad and the ugly. Nat. Neurosci. Rev. 2:444-447.

51. Benes, V. and Muckenthaler M. 2003. Standardization of protocols in cDNA microarray analysis. Trends Biochem. Sci. 28(5): 244-249.

52. Blalock, E. M., Chen, K-C., Sharrow, K., Herman, J. P., Porter, N. M., Foster, T. C., and Landfield, P. W. 2003. Gene microarrays in hippocampal aging: statistical profiling identifies novel processes correlated with cognitive impairment. J. Neurosci. 23(9):3807-3819.

53. Ball, C. A., Sherlock, G., Parkinson, H., Rocca-Sera, P., Brooksbank, C., Causton, H. C., Cavalieri, D., Gaasterland, T., Hingamp, P., Holstege, F., Ringwald, M., Spellman, P., Stoeckert, C. J. Jr., Stewart, J. E., Taylor, R., Brazma, A., Quackenbush, J.; and the Microarray Gene Expression Data (MGED) Society. 2002. Standards for microarray data. Science 298(5593):539.

54. Brazma, A., Hingamp, P., Quackenbush, J., Sherlock, G., Spellman, P., Stoeckert, C., Aach, J., Ansorge, W., Ball, C. A. Causton, H. C., Gaasterland, T., Glenisson, P., Holstege, F. C., Kim, I. F., Markowitz, V., Matese, J. C., Parkinson, H., Robinson, A., Sarkans, U., Schulze Kremer, S., Stewart, J., Taylor, R., Vilo, J., and Vingron, M. 2001. Minimum information about a microarray experiment (MIAME)-toward standards for microarray data. Nat. Genet. 29(4):365-371.

55. Velculescu, V. E., Zhang, L., Vogelstein, B., and Kinzler, K. W. 1995. Serial analysis of gene expression. Science 270:484-487.

56. Trendelenburg, G., Prass, K., Priller, J., Kapinya, K., Polley, A., Muselmann, C., Ruscher, K., Kannbley, U., Schmitt, A. O., Castell, S., Wiegand, F., Meisel, A., Rosenthal, A., and Dirnag, U. 2002. Serial analysis of gene expression identifies metallothionein-II as major neuroprotective gene in mouse focal cerebral ischemia. J. Neurosci. 22(14):5879-5888.

57. Evans, S. J., Datson, N. A., Kabbaj, M., Thompson, R. C., Vreugdenhil, E., De Kloet, E. R., Watson, S. J., and Akil, H. 2002. Evaluation of affymetrix gene chip sensitivity in rat hippocampal tissue using SAGE analysis. Eur. J. Neurosci. 16:409-413.

58. Datson, N. A., van der Perk-de Jong, J., van den Berg, M., de Kloet, E. R., and Vreugdenhil, E. 1999. MicroSAGE: a modified procedure for serial analysis of gene expression in limited amounts of tissue. Nucleic Acids Res. 27:1300-1307. 